\title{
THE EFFECT OF ENGLISH SPEECH ACTIVITY TOWARD THE PSYCHOLOGICAL ASPECT IN SPEAKING ENGLISH FOR THE SECOND SEMESTER STUDENTS OF ENGLISH DEPARTMENT AT UNIVERSITAS SULAWESI BARAT
}

\author{
Aco Syarif ${ }^{1}$ and Muthmainnah ${ }^{2}$ \\ Universitas Al Asyariah Mandar \\ lacosyarif95@gmail.com \\ ${ }^{2}$ muthmainnahunasman@gmail.com
}

\begin{abstract}
This research is aimed at finding out: (1) whether or not the use of English speech activity effects the students' motivation for the second semester students of English Department at Universitas Sulawesi Barat and (2) whether or not the second semester students of English Department at Universitas Sulawesi Barat are interested in speaking English through English speech activity. This research applied quasi-experimental research method. The population of the research was all second semester students of English Department at Universitas Sulawesi Barat. The researcher chose class II.A as experimental group (16 students) and class II.B as control group (16 students) as sample of the research. The data of the research were collected by using two kinds of instruments, namely speaking test and questionnaire. Speaking test (interview) was used to obtain data of the students' speaking ability and questionnaire was used to know the students interest in speaking through English speech activity. The result of data analysis showed that there was significant difference between the students' score who were taught by using English speech activity and re-telling. It was proved by the mean score of the experimental class which was higher than control group in posttest (79.06>73.37). Based on data analysis, the researcher concluded that: the use of English speech activity can improve students' speaking ability and make the students interested in speaking English.
\end{abstract}

Keywords : English speech activity, speaking, influence, improve

\begin{abstract}
Abstrak
Penelitian ini bertujuan untuk menemukan apakah: (1) penggunaan teknik pidato bahasa Inggris secara signifikan dapat mempengaruhi motivasi mahasiswa semester dua jurusan bahasa Inggris di Universitas Sulawesi Barat dan (2) mahasiswa semester dua jurusan bahasa Inggris di Universitas Sulawesi Barat tertarik belajar bahasa Inggris dengan teknik pidato bahasa Inggris.Penelitian ini menerapkan metode kuasi-eksperimental. Populasi penelitian ini adalah mahasiswa semester dua jurusan bahasa Inggris di Universitas Sulawesi Barat. Peneliti memilih kelas II.A sebagai grup eksperimen (16 siswa) dan II.B sebagai grup control (16 siswa) sebagai sampel penelitian. Data yang diolah dengan menggunakan dua instrumen penelitian yaitu test berbicara dan kuesioner. Test berbicara (wawancara) digunakan untuk memperoleh data kemampuan berbicara sementara kuesioner atau angket digunakan untuk menggunakan ketertarikan siswa dalam menggunakan teknik pidato bahasa Inggris.Hasil analisis data menunjukkan bahwa prestasi belajar mahasiswa berbeda secara signifikan antara mahasiswa yang diajar dengan menggunakan teknik pidato bahasa Inggris dan re-telling. Ini ditunjukkan dengan peroleh nilai rata-rata mahasiswa kelas eksperimen lebih tinggi dari kelas control pada tes akhir (79.06>73.37). Berdasarkan analisis data diatas maka peneliti menyimpulkan bahwa:
\end{abstract}


penggunaan teknik pidato bahasa Inggris dapat meningkatkan kemampuan berbicara siswa dan juga dapat membuat siswa tertarik belajar bahasa Inggris,

Kata kunci : pidato bahasa Inggris, berbicara, pengaruh, meningkatkan

\section{INTRODUCTION}

English as one of the foreign languages in Indonesia plays important roles in both written and oral communication. Until recently, English has become the compulsory foreign language subject taught in Indonesia. Some schools start from elementary level but mostly from junior high school until senior high schools and even up to graduate program level of education in Indonesia. English is one of the subjects in the core program of curriculum. One of the curricular objectives of English teaching in Indonesia is to enable the students to speak English. That makes challenging to the English teachers to make the students master English according to curriculum demand.

Allen (1997 : 211) stated that learning to speak English as second language and foreign language is a lengthy process. First the students must carefully repeat models and imitate the teacher. They may memorize basic sentences to gain confidence in their ability to speak English. They may practice sentences and do oral drills. These activities are all preliminary to actual conversation. In a sense, these activities may be termed vocalizing. Students are truly speaking only when they are generating their own sentences. In the classroom the teacher should try to create some speaking activities where the student should be encouraged to talk more in class and to express their own ideas, not simply what the teacher tells to say.

English subject has many handicaps or constraints. The students sometimes have low self-confidence to speak English well. They thought that English is a difficult subject and they do not yet know what the usefulness of English subject is. In this condition the teacher should be more creative and choose technique to increase the students' interest and self-confidence in speaking.

Another problem, the time allotted for classroom session is very limited (Macalister, 2010:22). On the other side, the academic setting cannot always provide opportunity for students to practice the English language and sufficient target language exposure to acquire. If these two things are not well managed, the students cannot benefit much from the learning activities and will result inadequate target language proficiency and fluency. To bridge the gaps, a teacher should make more classroom sessions and create learning interaction in order that the students can maximally be exposed to practice their speaking in the class.

In this research I would like to offer one alternative to overcome the problems particularly in learning speaking through English speech activity. I assume that English speech activity is a way to improve the students interest to learn English especially in speaking. Underlying the problems above, the researcher takes research under the title "The effect of English speech activity toward psychological aspect in speaking English for the second semester students' of English department at Universitas Sulawesi Barat “. 


\section{Problem Statement}

Referring to the background above, the researcher presents the problem statement as follows:

1. Can the use of English Speech activity improve the students' speaking ability for the second Semester Students of English Department at Universitas Sulawesi Barat?

2. Does English speech activity effect the students' motivation and interest in speaking?

\section{Objective of the Research}

Relating to the problem statement above, the objectives of this research is then specified to find out whether or not:

1. The use of English speech activity can improve students' speaking ability for the second Semester Students of English Department at Universitas Sulawesi Barat.

2. English speech activity effect the students' motivation and interest in speaking.

\section{REVIEW OF RELATED LITERATURE}

\section{Speaking}

a. What is Speaking

Speaking is a mean of oral activity that plays essential role in human interaction and communication when express their ideas, mind, and feeling to others adapted from widdowson (1990:155)

Allen et al (1997:211) reporter that learning to speak English as second language and foreign language is a lengthy process. First the students must carefully repeat models and imitate the teacher. They may memorize basic sentences to gain confidence in their ability to speak English. They may practice sentences and do oral drills. These activities are all preliminary to actual conversation. In a sense, these activities may be termed vocalizing. Students are truly speaking only when they are generating their own sentences. In the classroom the teacher should try to allow for some true speaking activity where the student should be encouraged to talk a great deal in class and to express their own ideas, not simply what the teacher tells to say.

Speaking in term of the usage is oral communication in expressing ideas to other people as partner of conversation. It means the speaker can express his ideas through the language. Widdowson (1990:37) stated that an act of communication through speaking is commonly performed in face to face interaction and occurs as part at dialogue or rather forms of verbal exchange. He further said that the act of speaking involves not only the production of sound but also the use of gesture, the movement of muscle of face, and indeed of whole of body. All of these non-vocal accompaniments of speaking as communication activity are transmitted through the visual medium.

Ludwia (2010:1) said that, one of the most challenging aspects of language acquisition is achieving speaking fluency. Though you might progress quickly in reading and listening comprehension, mastery of spoken English can pose a bigger challenge. If you want to be able to socialize in the English language 
without feeling self-conscious about your language abilities, working on a few key aspects of English can help you becomes a better party guest or host. Going beyond the intermediate level of spoken English can be a challenge, but one that you can surmount through a combination of guided practice and self study. Smith (2010:1) said that it is not only able to read and write English, but to be able to speak it well. We can communicate more effectively if we take the time and follow tips on speaking English well. .

b. The Kinds of Speaking Activities

Sasmedi (2008) classified that there are many kinds of speaking activities, those activities as follows:

1) Monologue

Monologue is that when one speaker uses spoken language for any length of time, as in speeches, lectures, readings, news broadcast, an`d the like.

2) Pair Work

Pair work involves two or more speakers and can be subdivided into those exchanges that promote social relationship (interpersonal) and those for which the purpose is to convey prepositional or factual information (transactional). In each case, participants may have a good deal of shared knowledge (background information or schemata).

3) Question and Answer Drills

The teacher can begin by simply questioning to the learner in this activity. But the learners have mastered the question pattern; they should practice questioning one another. After numbers of question forms have mastered, question and answer drill can cover a wide of variety topics. There are many topics about which question can be asked.

4) Retelling

Retelling is an interesting activity of speaking games for making relax of the students while speaking. It can increase motivation of the students to speak English, like guessing games, speech through actions, and tell again what have been heard.

\section{Motivaton}

One common question English teachers often ask themselves is, how do we motivate students to learn English. Students 'motivation has continually become a major concern for English teachers, novice or experienced, because students 'motivation is critical for the effectiveness of English teaching-and-learning adapted from Lisa (2010:188)

What is the relationship of motivation to learning? Rogers, Ludington and Graham (1999) describe motivation as an internal feeling; it is the drive that someone has to do something. Whenever students feel a desire or need for learning something, they are motivated. Any teacher knows that using the best curriculum, technology, and assessment will not make a difference if the students don't want to learn. Russell (1971) mentions that in former times, teachers simply - taught, students would sit quietly, disturb no one, do the assignment, and absorb knowledge flowing from teachers and textbooks. Is teaching as simple as that? The answer is - No. Teachers are dealing with many more students' behavior problems nowadays. Students are struggling more with the academic challenge 
than before. Interestingly, Rogers et al. (1999) indicate the problem is not that students are not motivated to learn, it's that they are not motivated to learn what teachers are teaching or in the way that they are being expected to learn.

\section{Interest}

\section{a. Definition of interest}

Talking about interest will take someone to think about his positive response or attitude to something he likes, enjoy, and appreciate which makes him having a desire to do. To clearly define what actually interest means some theorists will define it. Beside that Robert in Syukri (2009:34) stated that experimentally an interest is a response of liking which is present when we are aware of an object we prepare to reach to or when we are aware of our disposition toward the object we like.

b. Type of interest

There are four types of interest. They are expressed interest, inventoried interest, tested interest, and manifested interest adapted from Harmer (1991)

1) Expressed interest: it is a type of interest which is defined as verbal expression of liking or disliking. Something related to maturity and experience.

2) Inventoried interest: it is determined by interest checklist. Someone's interest is measured by asking him/her to answer a number of questions whether or not one likes or dislike certain activities or situation. Usually, pattern of how high and how low interest normally result, therefore, the observer or the test can begin to determine areas of liking or disliking.

3) Tested interest: measuring the knowledge of vocabulary one has in specific interest area, is a way to determine the tested interest. This measure is based on an assumption that interest is resulted in the accumulation of relevant information as well as specialized vocabulary.

4) Manifested interest: it is an observable interest in which an individual does not express his interest through words but through action based on the given activity. It is observable because the individuals' participation in the activity is visible. However, this kind of interest can also be misleading, for participation in a given activity may be necessary for certain fringe benefit to occur. Therefore, it is usually valuable to observe activities related to the events as well as individual' participation to determine the degree of manifest interest. Thus, lack of participation does not mean lack of interest, such as cost or time may affect participation and manifest interest.

\section{English Speech}

Definition of English Speech :

1) Adapted from Silverstone (2010) that English Speech is to foster selfconfidence promote interest speaking; provide an opportunity for students to improve their speaking skills by competing, and to recognize the best to encourage all.

2) Soldave (2010) points out that English speech is a very exciting and challenging activity. With appropriate help and guidance from the teachers, students will learn how to present ideas in a logical sequence and 
in effective language, and how to use public speaking techniques to capture the audience. The exciting experience of talking to a large audience from a stage, which may be nerve-racking at first, will certainly help develop students' confidence. It is also desirable to encourage students to organize speech activities within the class so that all the students can benefit.

\section{RESEARCH METHOD}

In this research the researcher applied quasi-experimental design, with nonequivalent control group design. It involved two groups; the experimental group was taught by using English speech activity technique while the control group was taught without English speech activity technique namely retelling . Both groups were given pretest and posttest.

The design would take the following form:

\begin{tabular}{|llll|}
\hline EG & $\mathrm{O}_{1}$ & $\mathrm{X}$ & $\mathrm{O}_{2}$ \\
\hline $\mathrm{CG}$ & $\mathrm{O}_{3}$ & $\mathrm{X}$ & $\mathrm{O}_{4}$ \\
\hline
\end{tabular}

Figure 3.1 Research design (adapted from Sugiono, 2013:116).

\section{FINDINGS AND DISCUSSIONS}

\section{A. Findings}

1. The Students' speaking ability

a. The percentage of students' speaking skill for pretest

Table 4.1 The percentage of students' pretest score

\begin{tabular}{cccccc}
\hline \multirow{2}{*}{ Classification } & \multirow{2}{*}{ Score } & \multicolumn{2}{c}{ Experimental Group } & \multicolumn{2}{c}{ Control Group } \\
\cline { 3 - 6 } & & $\mathrm{F}$ & $\%$ & $\mathrm{~F}$ & $\%$ \\
\hline Excellent & $9.6-10$ & 0 & 0 & 0 & 0 \\
Very good & $8.6-9.5$ & 2 & 12.5 & 1 & 6.25 \\
Good & $7.6-8.5$ & 5 & 31.25 & 5 & 31.25 \\
Fairly good & $6.6-7.5$ & 8 & 50 & 8 & 50 \\
Fair & $5.6-6.5$ & 1 & 6.25 & 2 & 12.5 \\
Poor & $3.6-5.5$ & 0 & 0 & 0 & 0 \\
Very poor & $0.0-3.5$ & 0 & 0 & 0 & 0 \\
\hline Total & & 16 & 100 & 16 & 100 \\
\hline
\end{tabular}

b. The percentage of students' speaking ability for posttest

Table 4.2 The percentage of students' posttest score

\begin{tabular}{cccccc}
\hline \multirow{2}{*}{ Classification } & \multirow{2}{*}{ Score } & \multicolumn{2}{c}{ Experimental group } & \multicolumn{2}{c}{ Control group } \\
\cline { 3 - 6 } & & F & $\%$ & F & $\%$ \\
\hline Excellent & $9.6-10$ & 3 & 18.75 & 2 & 12.5 \\
Very good & $8.6-9.5$ & 3 & 18.75 & 4 & 25 \\
Good & $7.6-8.5$ & 6 & 37.5 & 5 & 31.25 \\
Fairly good & $6.6-7.5$ & 4 & 25 & 5 & 31.25 \\
Fair & $5.6-6.5$ & 0 & 0 & 0 & 0 \\
Poor & $3.6-5.5$ & 0 & 0 & 0 & 0 \\
Very poor & $0.0-3.5$ & 0 & 0 & 0 & 0 \\
\hline Total & & 16 & 100 & 16 & 100 \\
\hline
\end{tabular}


c. The mean score and the standard deviation of the students' pretest for experimental and control group

Table 4.3 The mean score and standard deviation of students' pretest

\begin{tabular}{lcc}
\hline \multicolumn{1}{c}{ Class } & Mean Score & Standard Deviation \\
\hline Experimental group & 31.75 & 1.409 \\
Control group & 22.93 & 1.197 \\
\hline
\end{tabular}

d. The mean score and standard deviation of students' posttest for experimental and control group.

Table 4.4 The mean score and standard deviation of students' posttest

\begin{tabular}{lcc}
\hline \multicolumn{1}{c}{ Class } & Mean Score & Standard Deviation \\
\hline Experimental group & 68 & 2.062 \\
Control group & 56 & 1870 \\
\hline
\end{tabular}

2. The Students' Interest

Table 4.11 The percentage of students' interest of control group

\begin{tabular}{clcc}
\hline Category & Range & Frequency & $\%$ \\
\hline Strongly interested & $85-100$ & 1 & 6.25 \\
Interested & $69-84$ & 12 & 75 \\
Moderate & $52-68$ & 3 & 18.75 \\
Uninterested & $36-51$ & 0 & 0 \\
Strongly uninterested & $20-35$ & 0 & 0 \\
\hline Total & & 16 & 100 \\
\hline
\end{tabular}

Table 4.12 The mean score of students' interest of control group

\begin{tabular}{ccc} 
Total respondent & Total of students' score & Mean \\
\hline 16 & 1.174 & 73.37
\end{tabular}

Table 4.13 The percentage of students' interest of experimental group

\begin{tabular}{cccc}
\hline Category & Range & Frequency & $\%$ \\
\hline Strongly interested & $85-100$ & 3 & 18.75 \\
Interested & $69-84$ & 12 & 75 \\
Moderate & $52-68$ & 1 & 6.25 \\
Uninterested & $36-51$ & 0 & 0 \\
Strongly uninterested & $20-35$ & 0 & 0 \\
\hline Total & & 16 & 100 \\
\hline
\end{tabular}

Table 4.14 The mean score of students' interest of experimental group

\begin{tabular}{ccc}
\hline Total respondent & Total of students' score & Mean \\
\hline 16 & 1265 & 79.06 \\
\hline
\end{tabular}

\section{DISCUSSIONS}


The result of this research clearly indicate that the experimental group was more successful that the control group. A possible explanation for these results is that the students' motivation and interest before and after treatments were significantly different. There was influence of students' motivation and interest after treatment through the use of English speech activity. During treatment, the researcher gave explanation and instructions of what the student should do and should not do in their English speech activity in order that the students understood and apply it and that easier for the students to perform well in their speech. The students know what they have to say in the speech. Therefore, they speak fluently with clear stages and sequenced. In addition to this, the students in the experimental class understood the researcher' suggestion since they were informed of this explanation in the class. This understanding brings a lot of benefit for them, such as having a clear direction and less mental burden

While the control group did not show significant improvement, students in the control group seemed to be worried during their speech performances because they were unsure whether or not they did correctly. Feeling worried and being unsure affected them from performing competently. This data is supported by Syaiful (2008:149) points out that intrinsic motivation is motives which become active or its function doesn't need to be stimulated from outside because every individual has encouragement to do something, and He also report that extrinsic motivation is motives which become active and function because there is stimulus from outside.

Although both English speech activity and re-telling technique can be used in teaching speaking and they could improve the students' motivation and interest, however, English speech activity technique improved the students' motivation and interest more meaningful than re-telling technique. This technique was able to change the students' ability to speak better than before. So it can be inferred statistically based on the value of t-test that English speech activity technique is more effective in improving students' motivation and interest. This data is supported by Harmer et al (1991) states that there are two factors can affect student' motivation as well as their interest in learning, namely: intrinsic and extrinsic motivation. Intrinsic motivation is concerned what factors outside the learner. This data also is supported to the research finding conducted by Darma (2004) in her research "Improving motivation of the third grade students of SMUN 15 Makassar to speak English through English contest technique" which found the equal result. She reports that the students had high motivation in speaking English through English speech contest and the finding indicated that English contest technique could develop the students' speaking skill.

Based on the discussion above, it can be concluded that the English speech activity should be able to help students to perform well in the class. This conclusion is drawn from the data obtained in the literature and the research result found in this research. 


\section{CONCLUSIONS AND SUGGESTIONS}

\section{A. Conclusions}

Based on the findings and discussions in the previous chapter, the researcher concludes that:

1. The use of English speech activity technique could improve the students' speaking ability for the second semester students at Universitas Sulawesi Barat.

2. The use of English speech activity technique effects the students' motivation and interest for the second semester students at Universitas Sulawesi Barat to speaking English. English speech activity technique is very exciting and challenging activity. It encourages the students to improve their motivation and interest in speaking.

\section{B. Suggestions}

Based on the conclusions above, the researcher would like to give some suggestions.

1. English lecturers

The English lecturers are suggested to use English speech activity technique as one technique that can be used in teaching process.

2. Further researcher

Based on this research, the researcher knows that English speech activity is interesting activity for the students. So the researcher suggests to further researchers to continue this research with different method.

\section{Government}

The researcher suggests to the government to make good relation and cooperation with all of the colleges or schools, and the government ought to make speech contest so that the students can improve their motivation and interest by English speech activity.

\section{REFERENCES}

Allen, E. D. and Valette, R. M. 1997. Classroom Technique: Foreign Languages and English as A Second Language. New York: Harcourt Brace Jovanovish. Inc.

Asriati, 2010. Using Cooperative Learning Technique to Improve Students' Motivation in Speaking English. Unpublished Thesis. Makassar: Graduated Program UNM.

Darma, 2004.Improving motivation of the third grade students of SMUN 15 Makassar. Unpublished Thesis. Makassar: Graduated Program UNM.

Harmer, Jeremy. 1991. The Practice of English Language Teaching. New York: Longman Group UK Limited.

Lisa, hsu. 2010. National Taichung Institute of technology. Taiwan

Ludwia. 2010. How to Speak English Language. Online (http://www.Ehow.com/about How-to-speak-english-language.html) retrieved on Mar 212015.

Macalister, John. 2010. Language Curriculum Design. New York: I.S.P nation. 
Muttaqin, 1992. Activating Students in Speaking English through Pair Task. Unpublished Thesis. Ujung Pandang: FPBS IKIP.

Russel, I .L (1971). Motivation Southem Illmois University W.C Brown Company Publisher

Silverstone, L. 2010. How to Gain Self Confidence. Online (http://www. Ehow.com/ about how-to-gain- self-confidence. html) retrieved on March 202015.

Sugiono, 2013. Metode Penelitian Pendidikan : Pendekatan kualitatif, kualitatif dan $R \& D$. Bandung; Alfabeta.

Soldave. 2010. English Speech Contest. Online (http://soldave. Ismysite.co.uk/bjginjapan) retrieved on March 202015.

Syaiful Bahri. 2008. Psikologi Belajar. Jakarta: Rineka Cipta.

UMPAR, 2013. Pedoman penulisan tesis Program studi pendidikan bahasa inggris program pasca sarjana Universitas Muhammadiyah parepare. Parepare.

Sasmedi. 2008. Self Confidence in Speaking English. Unpublished Thesis. Makassar: Graduate Program UNM.

Widdowson. H. G. 1990. Teaching Language as Communication. New York: Oxford. 